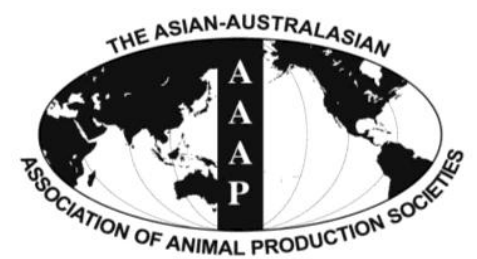

Asian Australas. J. Anim. Sci.

Vol. 26, No. $6: 820-826$ June 2013

http://dx.doi.org/10.5713/ajas.2012.12689

www.ajas.info

pISSN 1011-2367 elSSN 1976-5517

\title{
Effect of Plants Containing Secondary Compounds with Palm Oil on Feed Intake, Digestibility, Microbial Protein Synthesis and Microbial Population in Dairy Cows
}

\author{
N. Anantasook, M. Wanapat*, A. Cherdthong and P. Gunun \\ Tropical Feed Resources Research and Development Center (TROFREC), Department of Animal Science, \\ Faculty of Agriculture, Khon Kaen University, Khon Kaen, 40002, Thailand
}

\begin{abstract}
The objective of this study was to determine the effect of rain tree pod meal with palm oil supplementation on feed intake, digestibility, microbial protein synthesis and microbial populations in dairy cows. Four, multiparous early-lactation HolsteinFriesian crossbred (75\%) lactating dairy cows with an initial body weight (BW) of $405 \pm 40 \mathrm{~kg}$ and $36 \pm 8$ DIM were randomly assigned to receive dietary treatments according to a $4 \times 4$ Latin square design. The four dietary treatments were un-supplementation (control), supplementation with rain tree pod meal (RPM) at $60 \mathrm{~g} / \mathrm{kg}$, supplementation with palm oil (PO) at $20 \mathrm{~g} / \mathrm{kg}$, and supplementation with RPM at $60 \mathrm{~g} / \mathrm{kg}$ and PO at $20 \mathrm{~g} / \mathrm{kg}$ (RPO), of total dry matter intake. The cows were offered concentrates, at a ratio of concentrate to milk production of $1: 2$, and chopped $30 \mathrm{~g} / \mathrm{kg}$ of urea treated rice straw was fed ad libitum. The RPM contained condensed tannins and crude saponins at 88 and $141 \mathrm{~g} / \mathrm{kg}$ of DM, respectively. It was found that supplementation with RPM and/or PO to dairy cows diets did not show negative effects on feed intake and ruminal $\mathrm{pH}$ and $\mathrm{BUN}$ at any times of sampling ( $\mathrm{p}>0.05)$. However, RPM supplementation resulted in lower crude protein digestibility, $\mathrm{NH}_{3}-\mathrm{N}$ concentration and number of proteolytic bacteria. It resulted in greater allantoin absorption and microbial crude protein $(\mathrm{p}<0.05)$. In addition, dairy cows showed a higher efficiency of microbial N supply (EMNS) in both RPM and RPO treatments. Moreover, NDF digestibility and cellulolytic bacteria numbers were highest in RPO supplementation $(\mathrm{p}<0.05)$ while, supplementation with RPM and/or PO decreased the protozoa population in dairy cows. Based on this study, supplementation with RPM and/or PO in diets could improve fiber digestibility, microbial protein synthesis in terms of quantity and efficiency and microbial populations in dairy cows. (Key Words: Condensed Tannins, Crude Saponins, Rain Tree Pod Meal, Palm Oil, Rumen Microorganism, Ruminant)
\end{abstract}

\section{INTRODUCTION}

In the past few decades, feed additives such as antibiotics were used in ruminant production for optimization of the rumen fermentation pattern and to improve feed intake and efficiency (Abdl-Rahman, 2010; Patra, 2011). However, presently most of these supplements are not used routinely because of toxicity problems in the host animals and microbial adaptation. Most importantly, there is an increased awareness of the public health aspects of additives such as residues in milk and meat and the possibility of developing bacterial resistance to antibiotics. Consequently, the use of antibiotics as a feed additive has been banned in the European Union (European Union,

\footnotetext{
* Corresponding Author: Metha Wanapat. Tel: +66-43-202368, Fax: +66-43-202368, E-mail: metha@kku.ac.th

Submitted Dec. 12, 2012; Accepted Feb. 14, 2013; Revised Feb. 24, 2013
}

2003; Russell and Houlihan, 2003).

Accordingly, there is a greater interest in using plants and plant extracts such as those that contain secondary compounds such as tannins and saponins with antimicrobial properties which could be exploited in animal nutrition to manipulate rumen fermentation and improve feed efficiency (Cowan, 1999; Kamra et al., 2008; Sallam et al., 2009). Rain tree pod meal, which contains condensed tannins and saponins, has the potential to manipulate rumen fermentation by depressing protozoa and methanogens thereby reducing methane production in in vitro (Anantasook and Wanapat, 2012).

Moreover, dietary lipids are potent modifiers of ruminal fermentation and may offer a nutritional strategy to reduce protozoal predation and intraruminal recycling of bacterial protein, thus improving the efficiency of dietary protein utilization and mitigating $\mathrm{N}$ losses in ruminant animals (Hristov and Jouany, 2005). Moreover, feeding animals 
with vegetable oils such as soybean oil has the potential to reduce methanogenic bacteria (Mao et al., 2010). Therefore, the objective of this study was to investigate the supplementation with rain tree pod meal and palm oil on feed intake, digestibility, microbial protein synthesis and microbial populations in dairy cows.

\section{MATERIAL AND METHODS}

\section{Animals, diets and experimental design}

Four, multiparous mid-lactation Holstein-Friesian crossbred $(75 \%$ Holstein-Friesian with $25 \%$ Thai native breed) lactating dairy cows with initial BW of $405 \pm 40 \mathrm{~kg}$ and $36 \pm 8$ DIM were used in the experiment. Cows were randomly assigned to receive dietary treatments according to a $4 \times 4$ Latin square design to investigate the effect of condensed tannins (CT) and saponins (SP) from rain tree pod meal (RPM) with palm oil (PO) on feed intake, digestibility, microbial protein synthesis and microbial population in dairy cows.

The four dietary treatments were un-supplemented (control), supplementation with RPM at $60 \mathrm{~g} / \mathrm{kg}$, supplementation with $\mathrm{PO}$ at $20 \mathrm{~g} / \mathrm{kg}$, and supplementation with RPM at $60 \mathrm{~g} / \mathrm{kg}$ and PO at $20 \mathrm{~g} / \mathrm{kg}$ (RPO), of total dry matter intake. The RPM was prepared by the following, i) collect rain tree pods with black-brown coloration from ground; ii) chop rain tree pods with chopping machine; iii) sun dry rain tree pods for two-three days; iv) grind rain tree pods with grinding machine. The concentrate mixed diets were formulated to be at $181 \mathrm{~g} / \mathrm{kg} \mathrm{CP}$ and $806 \mathrm{~g} / \mathrm{kg} \mathrm{TDN}$, dry matter basis. The cows were offered concentrate, at a ratio of concentrate to milk production of 1:2, and chopped $30 \mathrm{~g} / \mathrm{kg}$ of urea treated rice straw was fed ad libitum. The ingredients and chemical composition of diets are shown in the Table 1.

Cows were housed in individual pens and received free choice of clean fresh water and mineral blocks that were available at all times. The experiment was run in four periods, each experimental period lasted for $21 \mathrm{~d}$, the first $14 \mathrm{~d}$ for treatment adaptation and for feed intake measurements whist the last $7 \mathrm{~d}$ were for sample collection of feeds, feces, and urine. Body weights were measured at the first and last days of sampling.

\section{Data collection, analysis and sampling procedures}

Feeds and refusals were sampled daily during the collection period and were composited by period prior to chemical analyses. Feeds, fecal and urine samples were collected during the last seven days of each period. Fecal samples were collected at 09.00 or $12.00 \mathrm{~h}$ by rectal sampling whilst urine samples were collected by spot sampling. Urination was induced by manual stimulation of the vulva; the sample was collected at 09.00 and/or $12.00 \mathrm{~h}$.
Table 1. Ingredients and chemical composition of concentrate, urea treated rice straw and rain tree pod meal used in the experiment

\begin{tabular}{|c|c|c|c|}
\hline Item & Concentrate & $\mathrm{UTRS}^{1}$ & $\mathrm{RPM}^{2}$ \\
\hline \multicolumn{4}{|l|}{ Ingredient ( $\mathrm{g} / \mathrm{kg}$ of dry matter) } \\
\hline Cassava chip & 459 & & \\
\hline Rice bran & 67 & & \\
\hline Brewery grain & 137 & & \\
\hline Palm kernel meal & 139 & & \\
\hline Coconut meal & 118 & & \\
\hline Urea & 30 & & \\
\hline Molasses & 30 & & \\
\hline Mineral premix ${ }^{3}$ & 10 & & \\
\hline $\mathrm{Salt}^{4}$ & 5 & & \\
\hline Sulfur & 5 & & \\
\hline \multicolumn{4}{|l|}{ Chemical composition } \\
\hline \multirow[t]{2}{*}{ Dry matter $(\mathrm{g} / \mathrm{kg})$} & 913 & 511 & 928 \\
\hline & \multicolumn{3}{|c|}{------ g/kg of dry matter ------- } \\
\hline Organic matter & 937 & 862 & 956 \\
\hline Crude protein & 181 & 57 & 164 \\
\hline Condensed tannins & - & - & 88 \\
\hline Crude saponins & - & - & 141 \\
\hline Neutral detergent fiber & 218 & 712 & 284 \\
\hline Acid detergent fiber & 183 & 537 & 231 \\
\hline Total digestible nutrients ${ }^{5}$ & 806 & 515 & - \\
\hline \multicolumn{4}{|c|}{$\begin{array}{l}{ }^{1} \text { UTRS }=3 \% \text { urea treated rice straw. } \\
{ }^{2} \text { RPM }=\text { Rain tree pod meal. } \\
{ }^{3} \text { Minerals and vitamins (each kg contains): Vitamin A: } 10,000,000 \mathrm{IU} \\
\text { Vitamin E: 70,000 IU; Vitamin D: } 1,600,000 \mathrm{IU} \text {; Fe: } 50 \mathrm{~g} \text {; Zn: } 40 \mathrm{~g} \text {; Mn } \\
40 \mathrm{~g} \text {; Co: } 0.1 \mathrm{~g} \text {; } \mathrm{Cu}: 10 \mathrm{~g} \text {; Se: } 0.1 \mathrm{~g} \text {; I: } 0.5 \mathrm{~g} \text {. } \\
{ }^{4} \mathrm{NaCl}{ }^{5} \text { Calculated value. }\end{array}$} \\
\hline
\end{tabular}

When fecal or urine samples were taken at $3 \mathrm{~h}$ intervals, two successive samples were combined and used as one sample. Composited fecal samples were dried at $60^{\circ} \mathrm{C}$, ground (1 mm screen using Cyclotech Mill, Tecator, Sweden) and then analysed for dry matter (DM), ash and crude protein (CP) content (AOAC, 1995), neutral detergent fiber (NDF), acid detergent fiber (ADF) (Van Soest et al., 1991) and acid insoluble ash (AIA). AIA was used to estimate digestibility of nutrients (Van Keulen and Young, 1977).

At the end of each period, rumen fluid and jugular blood samples were collected at 0 and $4 \mathrm{~h}$ after feeding. Approximately $200 \mathrm{ml}$ of rumen fluid was taken from the rumen by a stomach tube connected to a vacuum pump at each time at the end of each period. Rumen fluid was immediately measured for $\mathrm{pH}$ using a portable $\mathrm{pH}$ meter (Hanna Instrument HI 8424 microcomputer, Singapore). Rumen fluid samples were filtered through four layers of cheesecloth. Samples were divided into three portions; the first portion was used for ammonia-nitrogen $\left(\mathrm{NH}_{3}-\mathrm{N}\right)$ analysis with $5 \mathrm{ml}$ of $\mathrm{H}_{2} \mathrm{SO}_{4}$ added to $50 \mathrm{ml}$ of rumen fluid. The mixture was centrifuged at $16,000 \times \mathrm{g}$ for $15 \mathrm{~min}$, and 
the supernatant was stored at $-20^{\circ} \mathrm{C}$ before $\mathrm{NH}_{3}-\mathrm{N}$ analysis using the Kjeltech Auto 1030 analyzer. A second portion was fixed with $10 \%$ formalin solution in sterilized $0.9 \%$ saline solution. The total direct count of protozoa was made by the methods of Galyean (1989) based on the use of a haemacytometer (Boeco, Hamburg, Germany). The third portion was used to culture bacteria using a roll-tube technique (Hungate, 1969) to identify bacterial groups (cellulolytic, proteolytic, amylolytic and total viable count bacteria).

Urine samples were analyzed for allantoin and creatinine in urine by high-performance liquid chromatography (HPLC) as described by Chen and Gomes (1995). The amount of microbial purines absorbed was calculated from purine derivative excretion based on the relationship derived by Chen and Gomes (1995).

A blood sample (about $10 \mathrm{ml}$ ) was collected from a jugular vein (at the same time as rumen fluid sampling) into tubes containing $12 \mathrm{mg}$ of EDTA, and plasma separated by centrifugation at $500 \times \mathrm{g}$ for $10 \mathrm{~min}$ (Table Top Centrifuge PLC-02, USA) and stored at $-20^{\circ} \mathrm{C}$ until analysis of blood urea nitrogen (BUN) according to the method of Crocker (1967).

\section{Statistical analysis}

All data were statistically analyzed according to a $4 \times 4$ Latin square design using the ANOVA procedure of SAS (1996). Differences between treatment means were determined by Duncan's New Multiple Range Test (Steel and Torrie, 1980). Differences between means with $\mathrm{p}<0.05$ were accepted as representing statistically significant differences.

\section{RESULTS AND DISCUSSION}

\section{Effect on feed intakes and nutrient digestibility}

Feed intake and nutrient digestibility as influenced by RPM and/or PO supplementation are presented in Table 2. The results show that total feed intake, intake of urea treated rice straw and concentrate, digestibility of dry matter, organic matter, and ADF were not affected by feed supplementation ( $p>0.05)$. Pilajun and Wanapat (2011) also found that adding $30 \mathrm{~g} / \mathrm{kg}$ mangosteen peel to the diet had no effect on feed intake. However, Otaru et al. (2011) proposed that voluntary feed intake will be decreased when goats receive diets with PO higher than $40 \mathrm{~g} / \mathrm{kg}$ DM intake. Although feed intake was not affected by diet supplementation, protein digestibility was lower while NDF digestibility was higher with RPM and RPO supplementation, respectively. Ngamsaeng et al. (2006) found that feeding high levels of dietary SP and/or CT decreased ruminal apparent digestibility, especially of $\mathrm{N}$ which therefore increased the flow of material to the duodenum (Klita et al., 1996). Similar to Barry and Manley (1984) who reported that the CT from Lotus pedunculatus can increase post ruminal flow of nitrogen and essential amino acids by binding with protein to form tannin-protein complexs, thus increasing rumen by-pass protein. Moreover, Palmquist (1994) indicated that fiber digestion will be restricted when ruminants receive diets with a fat content higher than $70 \mathrm{~g} / \mathrm{kg}$ DM intake, a level which is higher than in the present study (20 g/kg DM intake). However, Mapato et al. (2012) and Lunsin et al. (2012) found that supplementation of sunflower oil and rice bran oil at 60 $\mathrm{g} / \mathrm{kg}$ DM intake, respectively decreased digestion coefficients of DM, OM and NDF in lactating dairy cows.

Table 2. Effect of rain tree pod meal and palm oil supplementation on feed intake and digestibility

\begin{tabular}{|c|c|c|c|c|c|c|}
\hline$\overline{\text { Items }}$ & Control $^{1}$ & RPM & $\mathrm{PO}$ & RPO & SEM & $\overline{p \text {-value }}$ \\
\hline \multicolumn{7}{|c|}{ UTRS DM intake } \\
\hline $\mathrm{kg} / \mathrm{d}$ & 6.1 & 6.2 & 6.2 & 6.2 & 0.31 & 0.35 \\
\hline$\% \mathrm{BW}$ & 1.5 & 1.5 & 1.5 & 1.5 & 0.12 & 0.20 \\
\hline \multicolumn{7}{|c|}{ Concentrate DM intake } \\
\hline $\mathrm{kg} / \mathrm{d}$ & 6.1 & 7.0 & 6.6 & 7.4 & 0.62 & 0.32 \\
\hline$\% \mathrm{BW}$ & 1.5 & 1.8 & 1.6 & 1.9 & 0.31 & 0.49 \\
\hline \multicolumn{7}{|c|}{ Total DM intake } \\
\hline $\mathrm{kg} / \mathrm{d}$ & 12.2 & 13.2 & 12.6 & 13.6 & 0.35 & 0.41 \\
\hline$\% \mathrm{BW}$ & 2.9 & 3.1 & 3.0 & 3.1 & 0.42 & 0.21 \\
\hline \multicolumn{7}{|c|}{ Apparent digestibility (\%) } \\
\hline DM & 63.2 & 65.4 & 65.6 & 66.4 & 0.52 & 0.25 \\
\hline OM & 67.1 & 68.4 & 68.8 & 68.6 & 0.38 & 0.56 \\
\hline $\mathrm{CP}$ & $66.6^{\mathrm{a}}$ & $60.4^{\mathrm{b}}$ & $65.9^{\mathrm{a}}$ & $62.8^{\mathrm{ab}}$ & 0.61 & 0.03 \\
\hline $\mathrm{NDF}$ & $63.8^{\mathrm{a}}$ & $64.5^{\mathrm{a}}$ & $64.0^{\mathrm{a}}$ & $65.9^{\mathrm{b}}$ & 0.36 & 0.04 \\
\hline $\mathrm{ADF}$ & 49.6 & 51.2 & 51.7 & 51.1 & 0.74 & 0.68 \\
\hline
\end{tabular}

${ }^{\mathrm{ab}}$ Values on the same row with different superscripts differed $(\mathrm{p}<0.05)$.

${ }^{1} \mathrm{RPM}=$ Rain tree pod meal $60 \mathrm{~g} / \mathrm{kg}$ DMI, PO = Palm oil $20 \mathrm{~g} / \mathrm{kg}$ DMI, RPO = Rain tree pod meal $60 \mathrm{~g} / \mathrm{kg}$ DMI+palm oil $20 \mathrm{~g} / \mathrm{kg}$ DMI. 
The depression following oil supplementation can be explained when oil is supplemented at a high level as oil may coat feed particles which prevents microbial attachment and attack thus reducing the rate of digestibility (Devendra and Lewis, 1973).

Effects on ruminal $\mathrm{pH}$, ammonia nitrogen and blood urea nitrogen

The effects of RPM and/or PO supplementation on ruminal $\mathrm{pH}$ and ammonia nitrogen $\left(\mathrm{NH}_{3}-\mathrm{N}\right)$ are presented in Table 3. Ruminal pH values did not differed between treatments and ranged from 6.6 to 6.7. These values were optimal for normal rumen fermentation, microbial growth and microbial activity (Wanapat, 1999). Moreover, BUN concentration in the present study were closer to the normal range as reported by Roseler et al. (1993) who found that balanced diets for lactating dairy cows were associated with average BUN concentration of $15 \mathrm{mg} / \mathrm{dl}$. The present study found that concentrations of BUN were 12.4 to $13.5 \mathrm{mg} / \mathrm{dl}$ and the ruminal $\mathrm{NH}_{3}-\mathrm{N}$ concentration was reduced by RPM and RPO supplementation. These results are similar to those of Grobner et al. (1982) who found a $15 \%$ reduction in ammonia concentration when SP was included at $60 \mathrm{mg} / \mathrm{kg}$ in the incubation medium. Moreover, addition of an ethanol extract of soapnut (Sapindus mukorossi) in an in vitro study decreased $\mathrm{NH}_{3}-\mathrm{N}$ concentration (Kamra et al., 2006). This could be due to $\mathrm{CT}$ producing a protein-tannin complexation, decreasing the availability of feed protein for ruminal degradation and ammonia nitrogen release (Makkar, 2003). Moreover, Wanapat et al. (2010) stated that supplementation of a $60 \mathrm{~g} / \mathrm{kg}$ mixture of coconut oil (CO) and sunflower oil decreased $\mathrm{NH}_{3}-\mathrm{N}$ concentration by depressing protein degradation. Furthermore, Mapato et al. (2010) indicated that $\mathrm{NH}_{3}-\mathrm{N}$ concentration reduced when dairy cows received $60 \mathrm{~g} / \mathrm{kg}$ of sunflower oil, which correlated with a lower CP digestibility. However, earlier studies reported that $\mathrm{NH}_{3}-\mathrm{N}$ concentration in the rumen of lamb and goat was not affected by PO supplementation, respectively (Dutta et al., 2008; Otaru et al., 2011).

\section{Effect on microorganism population}

The influence of RPM and/or PO supplementation on microorganism populations are shown in Table 4. Ruminal protozoa population was reduced through the addition of either RPM or PO in agreement with the previous work in an in vitro study (Kongmun et al., 2010) and an in vivo study (Mao et al., 2010; Pilajun and Wanapat, 2011). These could be due to PO being rich in C18-fatty acids which have the potential to depress protozoa numbers. On the other hand, Anantasook and Wanapat (2012) found that populations of protozoa decreased with supplementation with RPM containing CT and SP. Similarly, Guo et al. (2008) reported that tea SP have an inhibitory effect on protozoa populations. The sensitivity of protozoa towards plant secondary compounds may be explained by the presence of sterols in cell membranes (Newbold et al., 1997; Wina et al., 2005). Saponins might form complexes with sterol in the cell membrane of protozoa causing destruction of cell membrane (Francis et al., 2002). In contrast, cellulolytic bacteria incrreased with a combination of RPM and PO in the diet. The increased population of cellulolytic bacteria could be explained by plant secondary compounds and oils that have specific toxicity to protozoa. However, Pilajun and Wanapat (2011) reported that cellulolytic bacteria were not affected by either CO or MP supplementation in swamp buffalo. In addition, the population of proteolytic bacteria was decreased by RPM supplementation which may be related to a decreasing $\mathrm{NH}_{3}$ $\mathrm{N}$ concentration in the rumen. Jones et al. (1994) reported that growth of proteolytic bacteria was reduced by CT of the legume sainfoin (O. viciifolia). Wang et al. (2000) also observed that the growth of Ruminobacter amylophilus was

Table 3. Effect of rain tree pod meal and palm oil supplementation on ruminal $\mathrm{pH}$ and ammonia nitrogen concentration

\begin{tabular}{|c|c|c|c|c|c|c|}
\hline Items & Control $^{1}$ & RPM & PO & RPO & SEM & p-value \\
\hline \multicolumn{7}{|l|}{ Ruminal pH } \\
\hline 0 h-post feeding & 6.5 & 6.6 & 6.5 & 6.6 & 0.04 & 0.75 \\
\hline 4 & 6.6 & 6.6 & 6.6 & 6.6 & 0.02 & 0.79 \\
\hline Mean & 6.6 & 6.7 & 6.6 & 6.6 & 0.02 & 0.72 \\
\hline \multicolumn{7}{|l|}{$\mathrm{NH}_{3}-\mathrm{N}(\mathrm{mg} / \mathrm{dl})$} \\
\hline 0 h-post feeding & 13.2 & 10.7 & 11.8 & 11.0 & 0.28 & 0.38 \\
\hline 4 & $25.4^{\mathrm{a}}$ & $18.8^{\mathrm{b}}$ & $22.9^{\mathrm{ab}}$ & $21.4^{\mathrm{ab}}$ & 0.18 & 0.04 \\
\hline Mean & $19.6^{\mathrm{a}}$ & $17.4^{\mathrm{b}}$ & $19.5^{\mathrm{a}}$ & $17.6^{\mathrm{b}}$ & 0.19 & 0.04 \\
\hline \multicolumn{7}{|l|}{ BUN, mg/dl } \\
\hline 0 h-post feeding & 10.1 & 8.9 & 9.2 & 8.6 & 0.33 & 0.53 \\
\hline 4 & 13.5 & 13.9 & 14.2 & 13.7 & 0.41 & 0.14 \\
\hline Mean & 12.9 & 12.6 & 13.5 & 12.4 & 0.35 & 0.22 \\
\hline
\end{tabular}

${ }^{\mathrm{ab}}$ Values on the same row with different superscripts differed $(\mathrm{p}<0.05)$.

${ }^{1} \mathrm{RPM}=$ rain tree pod meal $60 \mathrm{~g} / \mathrm{kg}$ DMI, PO = palm oil $20 \mathrm{~g} / \mathrm{kg}$ DMI, RPO = rain tree pod meal $60 \mathrm{~g} / \mathrm{kg}$ DMI + palm oil $20 \mathrm{~g} / \mathrm{kg}$ DMI. 
Table 4. Effect of roughage to concentrate ratio and rain tree pod meal supplementation on microbial populations in the rumen

\begin{tabular}{|c|c|c|c|c|c|c|}
\hline$\overline{\text { Items }}$ & Control & RPM & $\mathrm{PO}$ & RPO & SEM & p-value \\
\hline \multicolumn{7}{|c|}{ Direct count, (cell/ml) } \\
\hline \multicolumn{7}{|l|}{ Protozoa $\left(\times 10^{6}\right)$} \\
\hline 0 h-post feeding & $19.3^{\mathrm{a}}$ & $13.2^{\mathrm{ab}}$ & $8.3^{\mathrm{b}}$ & $9.2^{\mathrm{b}}$ & 1.17 & 0.05 \\
\hline 4 & $15.0^{\mathrm{a}}$ & $8.5^{\mathrm{b}}$ & $6.8^{\mathrm{b}}$ & $6.3^{\mathrm{b}}$ & 0.64 & 0.02 \\
\hline Mean & $17.2^{\mathrm{a}}$ & $9.9^{\mathrm{b}}$ & $7.6^{\mathrm{b}}$ & $8.0^{\mathrm{b}}$ & 0.78 & 0.04 \\
\hline \multicolumn{7}{|c|}{ Total viable bacterial $\left(\times 10^{9} \mathrm{CFU}^{3} / \mathrm{ml}\right)$} \\
\hline 0 h-post feeding & 5.8 & 6.1 & 6.1 & 6.1 & 0.16 & 0.61 \\
\hline 4 & 6.6 & 6.6 & 6.6 & 6.7 & 0.14 & 0.84 \\
\hline Mean & 5.7 & 6.3 & 5.8 & 5.9 & 0.23 & 0.67 \\
\hline \multicolumn{7}{|c|}{ Cellulolytic bacteria $\left(\times 10^{8} \mathrm{CFU} / \mathrm{ml}\right)$} \\
\hline 0 h-post feeding & 3.6 & 3.8 & 3.6 & 4.5 & 0.24 & 0.76 \\
\hline 4 & $7.4^{\mathrm{a}}$ & $7.3^{\mathrm{a}}$ & $7.4^{\mathrm{a}}$ & $7.9^{\mathrm{b}}$ & 0.15 & 0.04 \\
\hline Mean & $5.3^{\mathrm{a}}$ & $5.5^{\mathrm{a}}$ & $5.5^{\mathrm{a}}$ & $6.6^{\mathrm{b}}$ & 0.23 & 0.04 \\
\hline \multicolumn{7}{|c|}{ Proteolytic bacteria $\left(\times 10^{8} \mathrm{CFU} / \mathrm{ml}\right)$} \\
\hline 0 h-post feeding & 2.3 & 2.6 & 2.5 & 2.5 & 0.12 & 0.83 \\
\hline 4 & $7.8^{\mathrm{a}}$ & $6.4^{\mathrm{b}}$ & $7.9^{\mathrm{a}}$ & $7.1^{\mathrm{ab}}$ & 0.11 & 0.04 \\
\hline Mean & $5.9^{\mathrm{a}}$ & $4.5^{\mathrm{b}}$ & $6.0^{\mathrm{a}}$ & $5.6^{\mathrm{ab}}$ & 0.10 & 0.14 \\
\hline \multicolumn{7}{|c|}{ Amylolytic bacterial $\left(\times 10^{8} \mathrm{CFU} / \mathrm{ml}\right)$} \\
\hline 0 h-post feeding & 6.9 & 6.8 & 6.7 & 6.7 & 0.23 & 0.88 \\
\hline 4 & 8.0 & 8.1 & 8.0 & 8.3 & 0.20 & 0.40 \\
\hline Mean & 6.2 & 6.3 & 6.3 & 6.4 & 0.12 & 0.29 \\
\hline
\end{tabular}

${ }^{\mathrm{ab}}$ Values on the same row with different superscripts differed $(\mathrm{p}<0.05)$.

${ }^{1} \mathrm{RPM}=$ Rain tree pod meal $60 \mathrm{~g} / \mathrm{kg}$ DMI, PO = Plm oil $20 \mathrm{~g} / \mathrm{kg}$ DMI, RPO = Rain tree pod meal $60 \mathrm{~g} / \mathrm{kg}$ DMI+palm oil $20 \mathrm{~g} / \mathrm{kg}$ DMI.

reduced as a result of an alteration of the bacterial cell wall. The antimicrobial activities of tannins are ascribed to the interactions of tannins with the extracellular enzymes secreted by the cell wall of bacteria causing morphological changes of the cell wall. Tannins induce membrane disruption, have a direct action on microbial metabolism and cause a deprivation of substrates for microbial growth through the chelation of cations reducing their availability to microbes (Smith et al., 2005). In contrast, Chanthakhoun et al. (2011) reported that proteolytic bacteria were not affected by Phaseolus calcaratus supplementation. In the present study populations of total viable bacteria and amylolytic bacteria were not affected by either RPM or PO supplementation $(\mathrm{p}>0.05)$.

\section{Effect on microbial protein synthesis}

Microbial protein synthesis in the rumen provides the majority of protein supplied to the small intestine of ruminants, accounting for 50 to $80 \%$ of total absorbable protein (Firkins et al., 2007). In the present study, the excretion of creatinine and allantoin concentrations in urine were not affected in any of the treatments $(p>0.05)$ (Table 5). In contrast, allantoin absorption and microbial crude protein (MCP) were increased by RPM supplementation. The MCP flow from the rumen as a result of allantoin absorption ranged from 284.6 to $339.3 \mathrm{~g} / \mathrm{d}$, respectively.

Table 5. Effect of rain tree pod meal and palm oil supplementation on excretion of purine derivatives (PD) and microbial nitrogen supply in lactating dairy cows

\begin{tabular}{lcccccc}
\hline Items & Control $^{1}$ & RPM & PO & RPO & SEM & p-value \\
\hline Purine derivatives (mmol/d) & & & & & & \\
$\quad$ Allantoin excretion & 256.9 & 292.7 & 274.4 & 281.88 & 11.25 & 0.95 \\
Allantoin absorption & $284.6^{\mathrm{a}}$ & $339.3^{\mathrm{b}}$ & $303.1^{\mathrm{a}}$ & $307.7^{\mathrm{a}}$ & 9.50 & 0.04 \\
$\quad$ Urine creatinine & 26.1 & 27.6 & 26.5 & 27.3 & 0.47 & 0.34 \\
$\mathrm{MCP}^{1}(\mathrm{~g} / \mathrm{d})$ & $712.4^{\mathrm{a}}$ & $759.7^{\mathrm{b}}$ & $731.3^{\mathrm{a}}$ & $734.4^{\mathrm{a}}$ & 8.25 & 0.03 \\
$\mathrm{EMNS}^{2}(\mathrm{~g} / \mathrm{kg}$ OMDR) & $26.9^{\mathrm{a}}$ & $31.9^{\mathrm{b}}$ & $27.1^{\mathrm{a}}$ & $30.4^{\mathrm{b}}$ & 1.01 & 0.04 \\
\hline
\end{tabular}

${ }_{\mathrm{a}, \mathrm{b}}$ Means in the same row with different superscripts differ $(\mathrm{Pb} 0.05)$.

${ }^{1}$ Microbial crude protein $(\mathrm{MCP})(\mathrm{g} / \mathrm{d})=3.99 \times 0.856 \times \mathrm{mmol}$ of purine derivatives excreted (Galo et al., 2003).

${ }^{2}$ Efficiency of microbial $\mathrm{N}$ supply (EMNS), g/kg of OM digested in the rumen (OMDR) $=((\mathrm{MCP}(\mathrm{g} / \mathrm{d}) \times 1,000) / \mathrm{DOMR}(\mathrm{g}))$, assuming that rumen digestion $=65 \%$ of digestion in total tract. 
Moreover, supplementation of RPM or RPO resulted in the greatest microbial protein synthesis in terms of quantity and efficiency. Similarly, Anantasook et al. (2013) reported that efficiency of microbial protein synthesis was increased in dairy steers supplemented with RPM. Chanthakhoun et al. (2011) also found that feeding Phaseolus calcaratus hay resulted in increasing efficiency of microbial protein synthesis in swamp buffalo. This could be due to effect of RPM reducing the protozoal population which contributed significantly to intra-ruminal cycling of microbial $\mathrm{N}$ and reducing the EMPS (Jouany, 1996). Therefore, reducing protozoa populations could improve dietary $\mathrm{N}$ utilization and increase MPS flow to the intestine (Wang et al., 2012).

\section{CONCLUSIONS}

No negative effect was observed on feed intake when RPM and/ or PO was added to the diet of dairy cows. Furthermore, fiber digestibility and cellulolytic bacteria were increased withh supplementation with PO. Supplementation of RPM lowered CP digestibility, $\mathrm{NH}_{3}-\mathrm{N}$ concentration, proteolytic bacteria and protozoa populations which resulted in greater microbial crude protein. In addition, efficiency of microbial $\mathrm{N}$ supply was increased in both RPM and RPO treatments.

\section{ACKNOWLEDGEMENTS}

The authors would like to express most sincere thanks to the Tropical Feed Resources Research and Development Center (TROFREC), The Office of the Higher Education Commission and Thailand Research Fund (TRF) through the Royal Golden Jubilee Ph.D. Program, Department of Animal Science, Faculty of Agriculture, Khon Kaen University, for kind financial support, experimental animals, laboratory and the use of research facilities. Special thanks are also extended to Mr. Nirote Sornsungnern, Head of the Dairy Production Section, Khon Kaen University, Thailand.

\section{REFERENCES}

Anantasook, N. and M. Wanapat. 2012. Influence of rain tree pod meal supplementation on rice straw based diets using in vitro gas fermentation technique. Asian Australas. J. Anim. Sci. 25:325-334.

Anantasook, N., M. Wanapat and A. Cherdthong. 2013. Manipulation of ruminal fermentation and methane production by supplementation of rain tree pod meal containing tannins and saponins in growing dairy steers. J. Anim. Physiol. Anim. Nutr. DOI: 10.1111/jpn.12029

Abdl-Rahman, M. A. 2010. In vitro manipulation of rumen fermentation efficiency by fumaric acid-bentonite coupled addition as an alternative to antibiotics. J. Agric. Sci. 2:174180.
AOAC. 1995. Official Method of Analysis, $16^{\text {th }}$ ed. Animal Feeds: Association of Official Analytical Chemists, VA, USA.

Barry, T. N. and T. R. Manley. 1984. The role of condensed tannins in the nutritional value of Lotus pedunculatus for sheep. 2. Quantitative digestion of carbohydrates and proteins. Br. J. Nutr. 51:493-504.

Chanthakhoun, V., M. Wanapat, C. Wachirapakorn and S. Wanapat. 2011. Effect of legume (Phaseolus calcaratus) hay supplementation on rumen microorganisms, fermentation and nutrient digestibility in swamp buffalo. Livest. Sci. 140:17-23.

Chen, X. B. and M. J. Gomes. 1995. Estimation of microbial protein supply to sheep and cattle based on urinary excretion of purine derivative-an overview of 215 the technique details. Occasional Publication 1992. International Feed Resources Unit, Rowett Research Institute, Aberdeen, UK.

Cowan, M. M. 1999. Plants products as antimicrobial agents. Clin. Microbiol. Rev. 12:564-582.

Crocker, C. L. 1967. Rapid determination of urea nitrogen in serum or plasma without deproteinization. Am. J. Med. Technol. 33:361-365.

Devendra, C. and D. Lewis. 1973. The interaction between dietary lipids and fibre in the sheep 1. A comparison of the methods used for crude fibre and acid-detergent fibre estimations. Anim. Prod. 17:275-280.

Dutta, T. K., M. K. Agnihotri and S. B. N. Rao. 2008. Effect of supplemental palm oil on nutrient utilization, feeding economics and carcass characteristics in post-weaned Muzafarnagari lambs under feedlot condition. Small Rumin. Res. 78:66-73.

European Union. 2003. Regulation (EC) No. 1831/2003 of the European parliament of the council o 22 September 2003 on additives for use in animal nutrition. Off. J. Eur. Union, 268:29-43.

Firkins, J. L., Z. Yu and M. Morrison. 2007. Ruminal nitrogen metabolism: perspectives for integration of microbiology and nutrition for dairy. J. Dairy Sci. 90:E1-E16.

Francis, G., Z. Kerem, H. P. S. Makkar and K. Becker. 2002. The biology action of saponis in animal systems: A review. Br. J. Nutr. 88:587-605.

Galo, E., S. M. Emanuele, C. J. Sniffen, J. H. White and J. R. Knapp. 2003. Effects of a polymer-coated urea product on nitrogen metabolism in lactating Holstein dairy cattle. J. Dairy Sci. 86:2154-2162.

Galyean, M. 1989. Laboratory Procedures in Animal Nutrition Research. New Mexico State University.

Grobner, M. A., D. E. Johnson, S. R. Goodall and D. A. Benz. 1982. Sarsaponin effects on in vitro continuous flow fermentation of a high grain diet. J. Anim. Sci. 55:491-497.

Guo, Y. Q., J. X. Liu, Y. Lu, W. Y. Zhu, S. E. Denman and C. S. McSweeney. 2008. Effect of tea saponin on methanogenesis, microbial community structure and expression of mcrA gene, in cultures of rumen micro-organisms. Lett. Appl. Microbiol. 47:421-426.

Hristov, A. N. and J. P. Jouany. 2005. Factors affecting the efficiency of nitrogen utilization in the rumen. In: Nitrogen and Phosphorus Nutrition of Cattle and Environment (Ed. A. N. Hristov and E. Pfeffer). CAB International, Wallingford, UK. 117-166. 
Hungate, R. E. 1969. The Rumen and Its Microbes. Academic Press. New York.

Jones, G. A., T. A. McAllister, A. D. Muir and K. J. Cheng. 1994. Effects of sainfoin (Onobrychis viciifolia Scop.) condensed tannins on growth and proteolysis by four strains of ruminal bacterium. Appl. Environ. Microbiol. 60:1374-1378.

Jouany, J. P. 1996. Effect of rumen protozoa on nitrogen utilization by ruminants. J. Nutr. 126:1335-1346.

Kamra, D. N., A. K. Patra, P. N. Chatterjee, K. Ravindra, A. Neeta and L. C. Chaudhary. 2008. Effect of plant extract on methanogenesis and microbial profile of the rumen of buffalo. A brief overview. Aust. J. Exp. Agric. 48:175-178.

Kamra, D. N., N. Agarwal and L. C. Chaudhary. 2006. Inhibition of ruminal methanogenesis by tropical plants containing secondary compounds. Int. Congr. Ser. 1293:156-163.

Klita, P. T., G. W. Mathison, T. W. Fenton and R. T. Hardin. 1996. Effect of alfalfa root saponins on digestive function in sheep. J. Anim. Sci. 74:1144-1156.

Kongmun, P., M. Wanapat, P. Pakdee and C. Navanukraw. 2010 Effect of coconut oil and garlic powder on in vitro fermentation using gas production technique. Livest. Sci. 127:38-44.

Lunsin, R., M. Wanapat, C. Yuangklang and P. Rowlinson. 2012. Effect of rice bran oil supplementation on rumen fermentation, milk yield and milk composition in lactating dairy cows. Livest. Sci. 145:167-173.

Makkar, H. P. S. 2003. Effects and fate of tannins in ruminant animals, adaptation to tannins, and strategies to overcome detrimental effects of feeding tannin rich feeds. Small Rumin. Res. 49:241-256.

Mao, H. L., J. K. Wang, Y. Y. Zhou and J. X. Liu. 2010. Effects of addition of tea saponins and soybean oil on methane production, fermentation and microbial population in the rumen of growing lambs. Livest. Sci. 129:56-62.

Mapato, C., M. Wanapat and A. Cherdthong. 2010. Effect of urea treatment of straw and dietary level of vegetable oil on lactating dairy cows. Trop. Anim. Health Prod. 42:1635-1642.

Newbold, C. J., S. M. Hassan, J. Wang, M. E. Ortega and R. J. Wallace. 1997. Influence of foliage from African multipurpose trees on activity of rumen protozoa and bacteria. Br. J. Nutr. 78:237-249.

Ngamsaeng, A., M. Wanapat and S. Khampa. 2006. Evaluation of local tropical plants by in vitro rumen fermentation and their effects on fermentation end-products. Pak. J. Nutr. 5:414-418.

Otaru, S. M., A. M. Adamu, O. W. Ehoche and H. J. Makun. 2011. Effects of varying the level of palm oil on feed intake, milk yield and composition and postpartum weight changes of Red Sokoto goats. Small Rumin. Res. 96:25-35.

Palmquist, D. L. 1994. The role of dietary fats in efficiency of ruminants. J. Nutr. 124:1377S-1382S.
Patra, A. K. 2011. Effects of essential oils on rumen fermentation, microbial ecology and ruminant production. Asian J. Anim. Vet. Adv. 6:416-428.

Pilajun, R. and M. Wanapat. 2011. Effect of coconut oil and mangosteen peel supplementation on ruminal fermentation, microbial population, and microbial protein synthesis in swamp buffaloes. Livest. Sci. 141:148-154.

Roseler, D. K., J. D. Ferguson, C. J. Sniffen and J. Herrema. 1993. Dietary protein degradability effects on plasma and milk urea nitrogen and milk non protein in Holstein cow. J. Dairy Sci. 76:525-534.

Russell, J. B. and A. J. Houlihan. 2003. Ionophore resistance of ruminal bacteria and its potential impact on human health. FEMS Microbiol. Rev. 27:65-74.

Sallam, S. M. A., I. C. S. Bueno, P. Brigide, P. B. Godoy, D. M. S. S. Vitti and A. L. Abdalla. 2009. Efficacy of eucalyptus oil on in vitro ruminal fermentation and methane production. Options Mediterraneennes 85:267-272.

SAS. 1996. User's Guide: Statistic, Version 5. Edition. SAS. Inst, Cary, NC, USA.

Smith, A. H., E. Zoetendal and R. I. Mackie. 2005. Bacterial mechanisms to overcome inhibitory effects of dietary tannins. Microb. Ecol. 50:197-205.

Steel, R. G. D. and J. H. Torrie. 1980. Principles and Procedures of Statistics. McGraw Hill Book Co., New York, NY, USA.

Van Keulen, J. and B. A. Young. 1977. Evaluation of acid insoluble ash as a neutral marker in ruminant digestibility studies. J. Anim. Sci. 44:282-287.

Van Soest, P. J., J. B. Robertson and B. A. Lewis. 1991. Methods for dietary fiber neutral detergent fiber, and nonstarch polysaccharides in relation to animal nutrition. J. Dairy Sci. 74:3583-3597.

Wanapat, M. 1999. Feeding of ruminants in the tropicals base on local feed resources. Khon Kaen Publishing Company Ltd., Khon Kaen, Thailand. 236.

Wanapat, M., C. Mapato, R. Pilajun and W. Toburan. 2010. Effects of vegetable oil supplementation on feed intake, rumen fermentation, growth performance, and carcass characteristic of growing swamp buffaloes. Livest. Sci. 135:32-37.

Wang, J. K., J. A. Ye and J. X. Liu. 2012. Effects of tea saponins on rumen microbiota, rumen fermentation, methane production and growth performance-a review. Trop. Anim. Health Prod. 44:697-706.

Wang, Y., T. A. McAllister, L. J. Yanke and P. R. Cheeke. 2000. Effect of steroidal saponin from Yucca schidigera extract on ruminal microbes. J. Appl. Microbiol. 88:887-896.

Wina, E., S. Muetzel, E. Hoffmann, H. P. S. Makkar and K. Becker. 2005. Saponins containing methanol extract of Sapindus rarak affect microbial fermentation, microbial activity and microbial community structure in vitro. Anim. Feed Sci. Technol. 121:159-174. 